University of Nebraska - Lincoln

DigitalCommons@University of Nebraska-Lincoln

2011

The Working Class Promise: A Communicative Account of

Mobility-Based Ambivalences

Kristen Lucas

University of Nebraska-Lincoln, kristen.lucas@louisville.edu

Follow this and additional works at: https://digitalcommons.unl.edu/commstudiespapers

Part of the Inequality and Stratification Commons, Organizational Communication Commons, and the Work, Economy and Organizations Commons

Lucas, Kristen, "The Working Class Promise: A Communicative Account of Mobility-Based Ambivalences" (2011). Papers in Communication Studies. 12.

https://digitalcommons.unl.edu/commstudiespapers/12

This Article is brought to you for free and open access by the Communication Studies, Department of at DigitalCommons@University of Nebraska - Lincoln. It has been accepted for inclusion in Papers in Communication Studies by an authorized administrator of DigitalCommons@University of Nebraska - Lincoln. 


\title{
The Working Class Promise: A Communicative Account of Mobility-Based Ambivalences
}

\author{
Kristen Lucas
}

\begin{abstract}
In-depth interviews with 62 people with working class ties (blue-collar workers and adult sons and daughters of blue-collar workers) reveal a social construction of working class that imbues it with four core, positively valenced values: strong work ethic, provider orientation, the dignity of all work and workers, and humility. This constellation of values is communicated through a ubiquitous macrolevel discourse-which I coin the Working Class Promise - that elevates working class to the highest position in the social class hierarchy and fosters a strong commitment to maintain a working class value system and identity. However, this social construction is only a partial social construction. That is, these individuals do not question material, socioeconomic-based delineations of class boundaries (e.g., income, education level, occupational prestige). Consequently, their acceptance of structural class boundaries, combined with their high regard of working class values, positions social classes in ways that make the goals of the American Dream (i.e., class mobility) and the Working Class Promise (i.e., class maintenance) paradoxical. I argue that the paradox of social mobility that results from this partial social construction is the root of mobility-based ambivalences.
\end{abstract}

Keywords: working class, sociological ambivalence, discourses, American dream

Horatio Alger tales are quintessentially American. In these popular stories, the young and destitute protagonist turns away from the temptations of crime, works hard and honestly, and ultimately reaps the benefits of material success. These tales capture the heart of the American Dream: through hard work, innate talent, and a little bit of pluck and luck, anyone can achieve anything. Beyond the pages of fiction, there are countless examples of people rising from

Kristen Lucas (PhD, Purdue University) is an Assistant Professor in the Communication Studies Department at University of Nebraska-Lincoln. This research is an extension of her dissertation, which was directed by Patrice M. Buzzanell and funded by a Purdue Research Foundation dissertation grant. Correspondence to: Kristen Lucas, Department of Communication Studies, 436 Oldfather, University of Nebraska-Lincoln, Lincoln, NE 68588-0329, USA. Tel: (402) 472-6924; email: klucas3@unl.edu 
humble beginnings to achieve great material success or, at a minimum, middle class comfort (Carroll, 2002; Gardner \& Troupe, 2006; Serafin, 2007). Though these cases often are framed as rags-to-riches tales of unequivocal success, many similar stories are rife with class mobility-based ambivalences.

Class mobility-based ambivalences are well documented. Emotionally charged feelings of dislocation arise when people from blue-collar, working class backgrounds enter the world of white-collar, middle to upper class work. In contrast to all they have gained by upward social mobility, many feel a deep sense of loss. Sennett and Cobb (1972) wrote at length about the complicated uneasiness of class mobility. Individuals who grew up in working class families and rose to middle class careers became frustrated by the white-collar, "paper pushing" jobs they held. Lubrano (2004), himself an Ivy League-educated son of a bricklayer, noted that many of the upwardly mobile people he interviewed broke into tears as they described the uneasiness of having one foot in each class-based world, while not fully belonging to either. For these people, whom Lubrano terms "straddlers," social mobility is not only about success. It also is about the loss of a firm sense of belonging (see also Christopher, 2002; Engen, 2004; Register, 2001; Wilson, 2002).

In this essay, I argue that these deep-seated ambivalences arise from the paradoxical conflict between two ubiquitous macrolevel discourses: the American Dream and the Working Class Promise. Whereas the American Dream encourages social mobility (i.e., the vertical movement of individuals within a stratified social system from their social class of origin to a higher social class), the Working Class Promise implores people to maintain their working class membership and identity. Therefore, to succeed at one is necessarily to fail at the other.

To develop this argument, I begin by explaining the concept of sociological ambivalence and then articulate the connections between the American Dream discourse and social class mobility. Next, I map out the contours of the Working Class Promise discourse, drawing from interviews with blue-collar families, and explain its connection to social class maintenance. Then, I demonstrate how the partial social construction of the working class - a value-based system delimited by unquestioned socioeconomic boundaries - is at the heart of the structural paradox of social mobility. Finally, I describe how individuals negotiate their sociological ambivalences through processes of identity work.

\section{Ambivalence}

Initial forays into research on ambivalence focused on its psychological facets, which were tied to individuals' subjective emotional and cognitive states. In fact, the roots of ambivalence are found in psychiatry where the term first was coined in 1910 by Eugen Bleuler, a psychiatrist who specialized in schizophrenia (Merton \& Barber, 1963). However, attention later turned toward sources of ambivalent psychological states when Merton and Barber (1963) developed the concept of sociological ambivalence, which took into consideration how individuals were embedded in roles and social structures. They define ambiva- 
lence as "incompatible normative expectations of attitudes, beliefs, and behaviors" (p. 95). Even though most of the extant research on ambivalence focuses on tensions within relationships (e.g., professional- client relationships, Merton \& Barber, 1963; family care negotiations, Connidis \& McMullin, 2002; parentchild relationships, Lüscher \& Pillemer, 1998), ambivalence also can occur at an individual or intrapersonal level, such as is the case with class identity ambivalences (Savage, Bagnall, \& Longhurst, 2001; Wong, 2010).

Merton and Barber (1963) identify several sources of conflict contributing to sociological ambivalence. Among these, the one cited as most relevant to social mobility is the conflict that arises when individuals identify with two or more social statuses (or belong to one social status, but aspire toward another). In Coser's (1966) extension of Merton and Barber's essay, she explains that ambivalence is particularly strong during periods of transition, as status change requires simultaneous conformity to one group and nonconformity to another, with each entailing a different set of cultural expectations and values (see Kaufman, 2003). Merton and Barber also identify contradictory cultural values as another source that has possible ties to social mobility-based ambivalences. In these instances, widely held, incompatible cultural demands are placed onto society at large and/or particular roles or statuses (e.g., women should strive to have successful careers; but women should prioritize their families above all else). Merton and Barber refer to this kind of ambivalence as cultural conflict.

Connidis and McMullin (2002) provide a reconceptualization of sociological ambivalence that is particularly well-suited for studying ambivalence as related to social mobility. Their model of ambivalence, rooted in critical theory and linked to communication, defines ambivalence as "socially created contradictions that are made manifest in interaction" (p. 558). The crux of their argument is that there are structural systems of varying privilege and power (especially gender, class, race, ethnicity, and age) that place individuals in paradoxical binds. For example, they explain that gendered social relations construct expectations of women to be primary family caregivers (and to derive pleasure and satisfaction from this role), leaving women to negotiate the contradictory demands on their time as they juggle responsibilities of care giving and paid labor. Connidis and McMullin conclude that individuals who are embedded in social structures ultimately are able to exercise their agency by negotiating their ambivalences through interaction.

Taking Connidis and McMullin's (2002) argument one step further, the very social structures themselves - and therefore any ensuing structural contradictions - are brought into existence through communication. Social constructionists argue that meanings, culture, and shared expectations of any social position are socially constructed through communicative interaction (Berger \& Luckmann, 1966; Pearce, 1995; Shotter \& Gergen, 1994). Shotter and Gergen (1994) maintain that it is through ordinary talk and dialogue that the importance of issues is determined, that meanings are created and constrained, and that social groups are sustained. Pearce (1994) also espouses the importance of talk when he explains, "[w]hen we communicate, we are not just talking about the world, we are literally participating in the creation of the social universe" (p. 75). 
Therefore, it can be argued that sociological ambivalence is at its core a communicative phenomenon because it is through interaction and discourse that meanings of social structures are (re)produced. In order to understand the onset and negotiation of social class mobility ambivalences, it first is necessary to understand the American Dream in relation to social class.

\section{The American Dream and Social Mobility}

The American Dream often is considered to be the most potent ideology in American life. Its basic narrative is evident in a variety of contexts: It is a common story line in popular TV shows such as American Idol and movies such as The Firm and Working Girl (Winn, 2000, 2003). It is the back story of our national icons, such as media mogul Oprah Winfrey (Cloud, 1996). It is the central story of much political speech (Fisher, 1973; Rowland \& Jones, 2007). It is a story that has helped recruit Major League Baseball players from Cuba (Nomai \& Dionisopoulos, 2002), and lure African Americans to the Northern United States in the early 1900s through stories featured in a Chicago-based newspaper (DeSantis, 1998).

Although its ideals have been present in US culture for many generations (DeSantis, 1998; DeVitis \& Rich, 1996), the American Dream was first named and designated by Adams (1931) in these terms:

[The American Dream is] that dream of a land in which life should be better and richer and fuller for every man [sic], with opportunity for each according to his ability or achievement.... It is not a dream of motor cars and high wages merely, but a dream of a social order in which each man and each woman shall be able to attain to the fullest stature of which they are innately capable, and be recognized by others for what they are, regardless of the fortuitous circumstance of birth or position. (p. 404)

This excerpt from Adams captures the heart of Fisher's (1973) claim that the American Dream is composed of two unique and collaborating components: the materialistic myth and the moralistic myth. The materialistic myth focuses on the accumulation of wealth, and the moralistic myth on the egalitarian principles of brotherhood and equal worth and opportunity for all. Together these two myths, Fisher argues, characterize the United States as a culture. But the American Dream and the relative importance of its two myths are in constant flux, reinventing themselves for the current time (Kamp, 2009).

One way in which the reinvention of the American Dream is evident is in political speech. For example, Fisher (1973) analyzed the portrayal of the American Dream by presidential candidates Richard Nixon and George McGovern in the 1972 election. Fisher argues that each candidate presented a different version of the American Dream. Nixon reaffirmed the materialistic component of the myth and downplayed the moralistic elements; McGovern did the reverse. By voting for Nixon, Fisher claims, the American people had aligned themselves with their preferred, materialistic vision of the Dream. 
In their analysis of the political romance myth of the American Dream, Rowland and Jones (2007) compare speeches by Ronald Reagan and Barack Obama. They explain that Reagan privileged an individualistic variant of the Dream in his speeches, emphasizing that ordinary people can achieve extraordinary outcomes by following the prescriptions of American values, such as hard work and rugged individualism. In contrast, Rowland and Jones argue that Obama struck a balance between the individual/materialistic and communal/moralistic values of the American Dream in his 2004 Democratic National Convention address. In his widely acclaimed speech, Obama talked about what is possible through individual achievement bolstered by community and societal support programs. This more moralistic American Dream narrative was well received because of the careful balance between celebrating individual hard work and achievement and emphasizing the need for community support.

Despite the huge success with which Obama's address was met, the individualistic variant of the American Dream continues to take precedence over the communal variant. Kamp (2009) traces the cultural shift to favoring an individualistic and materialistic American Dream when he describes that over the generations, especially following the New Deal and post-World War II boom, there have been marked shifts toward hyperconsumerism and a pursuit of wealth as signs of achieving the Dream. Put into context, many Americans, particularly in the time leading up to and during the Great Recession, have been betrayed by the moralistic lessons of the American Dream. Work hard and you can achieve the American Dream was what they were taught. Work hard and you still might not make it was what they experienced.

Much of today's workforce has lived through the recession and deindustrialization of the early 1980s, shifting the economy out of tangible heavy industry into a more speculative, information- and service-driven economy. These workers have felt the effects of the dot-com boom and bust cycles, the collapse of Enron, the crash of stock and real estate markets, and a long-lasting unemployment epidemic. But these changes have been more than simple "ups and downs" of the market - they have brought new rules to the game of work and career (Buzzanell, 2000). Lifetime employment contracts are gone, replaced by lifetime employability and volatility.

However, people remain tantalized and affirmed by the materialistic variant of the American Dream made possible, in large part, by changes in financial policies and practices. Many Americans still own nice homes, courtesy of zerodown subprime mortgages. They still send their kids to college due to the availability of Sallie Mae student loans. They still have new clothes, fun-filled family vacations, expensive vehicles, and the latest electronic gizmos, purchased with credit cards. Even though signs point to current generations not doing as well as those before them, the material trappings of the American Dream can still be procured - at least in the short run. Therefore, because Americans have been betrayed by the moralistic variant and satisfied by the materialistic one, the core of the American Dream has come to rest in contemporary times on meritocracy as measured by individuals' material success. 
In that context, the American Dream is an important ideology in terms of directing people's careers. Jobs are the means for earning the resources by which attainment of the materialistic component of the American Dream is judged. Consequently, the American Dream serves as a directive for several key components of individuals' careers. It is a directive for how work should be done (work diligently) and what should be accomplished (make money, earn promotions, achieve more than the previous generation). The Dream also prescribes an ideal career path in which individuals work in a series of jobs that form an upward trajectory pattern (Hall \& Goodale, 1986). In short, this discourse constructs a strong belief that all individuals should do better than the previous generation, to be socially mobile, and to move "up" in the social class hierarchy.

\section{The Working Class Promise and Class Maintenance}

Moving up in the social class hierarchy is a foundation of the (materialistic) American Dream. Therefore, despite outward claims of classlessness and unencumbered meritocracy, the American Dream rests on a firm foundation of socioeconomic class and intergenerational mobility. Winn (2000) explains that the American Dream is based on the belief that the United States is a land of opportunity where individuals are not limited by class structures or other barriers. Yet, at the same time, the goal of the Dream is for individuals to achieve upward class mobility. Ironically then, belief in the American Dream is a belief in a classless society; yet, class structure must exist in order for mobility to occur.

For working class people in particular, the American Dream is complex. On one hand, it is an empowering discourse that provides to working class and working poor people a roadmap for how to attain social mobility. On the other hand, the American Dream often presents the working class as a starting point, not an end goal. So for many, working class is something to aspire to leave. (Granted, for working poor and "missing class" workers, a solidly working/ middle class position can be advancement and a sign of fulfilling the American Dream; see Newman \& Chen, 2007.)

Therefore, I turn to working class families to examine their articulation of social class and social mobility. The examination of interviews with 62 blue-collar family members, including fathers, mothers, and their adult sons and daughters, reveals a nuanced understanding of what it means to be working class in a postindustrial economy. ${ }^{1}$ When asked to define working class, participants acknowledged a variety of elements from textbook definitions: socioeconomic status indicators (e.g., "it's not poor and it's not what the world would consider rich"), capital-labor designations (e.g., "blue-collar lunchbox types"), and lack of on-the-job creativity and autonomy (e.g., "going to work, never having to think, being told what you have to do in a day"). As a result, they essentially delineated the boundaries of working class by socioeconomic indicators such as salary, education level, and occupational prestige. But at the heart of participants' class-based discourses is the belief that working class is a social structure that is imbued with positively regarded core values. 
Working class values emerged in a variety of ways: stories about personal work history, family folklore from previous generations, lessons and advice parents shared with their children, and discussions about work and the economy. In this section, I turn to discourses of the parents in particular because they presumably transmitted their values to their children. The social construction of working class is accomplished through communicating four core values: (a) work ethic, (b) provider orientation, (c) the dignity of all work and workers, and (d) humility.

Before explaining these values, two points must be clarified. First, these values certainly are not unique to the working class, as people in other socioeconomic classes also hold many of the same values. But these are core values in which working class people have much pride and around which they rally their identities. Second, the examples that follow, as well as the values they represent, are not mutually exclusive, discrete categories. That is, participants call upon these core values in simultaneous and overlapping ways when talking about work and career.

\section{Work Ethic}

The most prevalent theme in the families' discourses was work ethic. This theme is based on the ideal of hard work, a core value in the symbolic meaning of work for Americans (Bernstein, 1997). When participants were asked what they learned about work from family members and/or what they wanted to teach the younger generation about work, the first thing mentioned (in 60 out of 62 interviews) was the importance of hard work. For example, Arlene, a woman who was not particularly fond of her blue-collar factory job but nonetheless went to work every day, talked about the work ethic she inherited from her blue-collar father:

Well, like I said, I don't think he liked what he did [mining]. But you know, he went. There's that work ethic, you know. And I feel like I have that. And I guess that's pretty much where it came from. You may not want to go. Well yeah, you know, I can remember him saying [imitating his voice], "Yeah, I pick up that lunch bucket everyday and I go to work." [laugh] You may not like it, but there are things that you just do because you have to.

In addition to learning about the value of hard work from their own parents, the people I interviewed also explained that passing a strong work ethic onto their children was a top priority. Harold was in the unique position of working with his son in the mines. He explained, "at times, he worked for me. That was interesting to say the least. [laugh] He was a very good worker." Harold's wife, Helen, chimed in, "if he wasn't a good worker, he would've found his suitcase on the sidewalk. [laugh] Full. Maybe not. Maybe it would've been empty." I asked how they taught their son about hard work and, in particular, if they ever talked to him about it. Harold explained that he did not have to talk to his son because, "they knew that already. It was instilled. It was part of the everyday growing up. I don't want any lazy ones around." 
Tom was another father who instilled a strong work ethic in his children. He said:

Yeah, they started working at a young age, helping me out. Paper routes and working out at our camp in the woods. They've worked since they were old enough to walk almost. I've had them with me, doing my stuff I like to do. We used to burn wood [to heat our home], so they'd help me make the wood for the wood iron. Shovel snow. They worked quite hard when they were young. We instilled in them, yeah you have to work, if you're gonna live, you have to work.

For all these participants, hard work was akin to living-essential to their way of life and to the meanings of their lives. As such, work ethic was a central feature of work- and career-related talk in families.

\section{Provider Orientation}

Certainly, hard work was a core value of the working class community. But for the most part, it was not because people loved the actual work they were doing. Rather, their work ethic was motivated in large part by the second core value: provider orientation. This value is marked by a principal commitment to providing a "roof over their heads" and "food on the table." Providing also has expanded over the years to include other less essential items such as new school clothes, family vacations, and so forth.

Marvin was someone who put providing first. His wife, Mary, recalled an exchange between Marvin and one of their sons who had worked one summer at the mines. "He used to come home and say to his dad, 'How can you stand it?"' Marvin nodded slowly and hummed in agreement. I asked him, "How did you answer that question when he said, 'How can you stand it?"' Marvin said, "Uh, I can't really remember. I suppose I made the remark that, 'Well, you gotta have a job somewhere.' [laugh] Whatever. You gotta have an income." Mary remembered exactly what Marvin said. She turned to Marvin: "“I have to support you boys,' that's what you said." At that point Marvin elaborated:

You get accustomed to whatever you're doing, you know. It doesn't even pass your mind that it's, that somebody might think it's a dirty and unpleasant job. Like underground mining, it was dirty. But you got accustomed to the noise and the dirt. And you just went to work and that was it. You did your eight hours or so.

Vincent was another miner who was willing to do an unpleasant job to support his family. In fact, he took on the provider role early in life when he dropped out of high school to take a job at the mine so that he could financially support his mother and younger siblings when his father was diagnosed with a terminal illness. He reasoned that despite the "bad times," the level at which he was able to provide for his own children was a fair tradeoff for a less-than-perfect job:

I have to say, I have always said, a lot of people grumbled about the mines, you know, and that they weren't fair. They provided me with a very good life. I got no complaints. I mean, sure, there were bad times. But, you know, all in all it was a good life. I was able to provide for the kids decent. 
The provider orientation was appreciated by miners' wives, too. One of the wives talked about the tradeoff of personal safety her husband was willing to make in order to be a provider. Deborah explains:

Like I said, he made a good living. And we raised three kids with it. But I had mixed feelings. It was dangerous, the job he did, especially in the wintertime when he worked on the shovels outside and stuff. So, he's had a few close calls and stuff. But, I don't know, outside of that, I didn't really think too much about it. We supported our family and raised the kids. He had a good job.

In her comments, Deborah admits her concerns for her husband's safety but backgrounds those issues by focusing instead on his ability to support his family through his "good job."

Providing was an important value for this community as in many working class communities (see Lamont, 2000; Lucas, 2007). One thing that makes providing a unique value is that it trumps other reasons or concerns for work. For example, several workers explicitly acknowledged their willingness to trade off other potentially desirable traits (e.g., a clean job, steady day shift) in exchange for dirty jobs and shift work that offered higher wages and additional benefits that enabled them to be better providers. Therefore, the provider orientation value can and often does lead toward an instrumental work attitude prevalent among blue-collar workers (Thomas, 1989).

\section{Dignity of All Work and Workers}

The third core value that emerged from participants' discourses about work is a steadfast belief that all work and workers have dignity. Even more notable is that respondents juxtaposed high-status and low-status occupations to make their point. Many participants compared dirty work (e.g., ditch diggers, garbage collectors, fast food workers) to high-status occupations (e.g., doctors, lawyers, executives) to emphasize that from the most socially stigmatized work to the most admired occupations, every job has dignity. Additionally, it was made clear that dignity does not reside in the work, but instead it is the worker who is deserving of respect and dignity (Lucas, 2011).

For example, when asked about what kinds of work had the most dignity, Jim drew a comparison between doctors and appliance repairmen to explain the dignity of all work:

I think every type of work is important. You know, you look at a doctor and he's so intelligent and everything. But if his stove doesn't work, he's in big trouble. So you got to have the guy to fix the stove and all the way down the line. So, actually, it's nice to be a doctor and get paid more, but all the way down the line it's necessary, too.

Neil made a similar comparison by contrasting white- and blue-collar workers, high-and low-paid workers, and being "on top" compared to doing a "menial job."

[What kind of work] do I think has the most dignity? Any kind of work that's honest and fair. Whether you're working with your mind or work- 
ing with your hands. Whatever, whatever your individual talents are. Work is dignified no matter what. It's just that you have to do what you can do. ... Dignity and pay scale are two different things. The person doing the menial job is just as important as the guy on top. Just that one is getting paid more than the other.

In Neil's comments, every task is part of a larger whole and every task is equally important in that it fulfills some function in the scheme of everyday life. To engage in work that contributes to the broader community and to engage in work itself is meaningful. Charlie took his comparison a step further by acknowledging the importance of often-stigmatized dirty work (Ashforth \& Kreiner, 1999):

To me, any job that you do well should be perceived as someone who has dignity. I don't hold - we're all human, whether you're a Supreme Court justice or a guy we call Dr. Ains. The whole word together says "drains," Dr. Ains. And he works in sewers. Damn, he does a good job. And he solves your sewer problems. Why shouldn't he have as much dignity as anybody else? He's doing a task that needs to be done. I appreciate it.

What is important about Charlie's comment is that when he was asked, like everyone else, what kinds of work have the most dignity, he briefly responded with talk about jobs, but then equated "any job" to "someone" who has dignity, not "work" or "a job" that has dignity.

People in this study frequently juxtaposed high-status occupations against low-status dirty work to assert that all jobs are real jobs and, furthermore, that all jobs have dignity. Although they acknowledged that some job characteristics are better than others (e.g., full-time is better than part-time, enjoyable work is better than unenjoyable work, day shift is better than swing shift, high paying jobs are better than low paying ones), respondents believed that it was the very act of going to work, performing a needed (even if underappreciated) service, and doing so with respect for self and others that made all jobs "real" (see Clair, 1996) and bestowed on workers a sense of dignity (Lucas, 2011).

\section{Humility}

The final value that emerged in participants' discourses was humility. In this context, humility is a duty to be neither arrogant nor pretentious. Although people can show pride in their quality of work and can take pride in their accomplishments, the value of humility demands that people should not be prideful. That is, under no circumstances, should they believe themselves to be superior to other working people or deem any job holder as inherently better than any other. These lessons came in two distinct forms: the cautionary tale of someone who was not humble and the edifying tale of someone who was.

Among the cautionary tales, participants called upon specific instances when they or someone they knew were put down on the basis of their working class status. For example, Gail came to the defense of her daughter-in-law's 
fast food job: "Even in Gina's situation, she works at Burger King. People think that's such a stupid job. But it's not, you know. I mean she does the bookkeeping and stuff there on her shift. She's manager when she works." Later, when asked directly about what the term working class meant to them, Gary said, "Well you can't classify people. Anybody that works, it's important what they do." Then Gail added, "Yeah, but a lot of people classify themselves. You'll say well I'm a lawyer and I'm better than this guy who manages a restaurant or an iron worker or whatever." The moral of the story, in this case, is that people should not demean people who work in low-status jobs and should recognize the value of their labor.

In contrast, participants also shared stories about how they remained humble even when they experienced moderate levels of advancement within their mining careers. Ray explained:

Like I said, in the mines I worked both hourly and salary. And I didn't feel in any position I was ever in, any better than anybody else. I really never looked down on anybody.... I feel everybody's pretty much equal. I always felt that the working class, everybody is just as important as anybody else. Right down to the guy that cleans the floor to the guy that does the paperwork in the office. Both jobs got to be done. You know, no matter what you do, you wouldn't be there if they didn't need you.

Carl was a miner who eventually was promoted to a salaried, supervisory position at the mine. In his account of his promotion, he emphasized his own humility. When asked what his parents thought about working at the mines, he said:

Oh, I think they thought that it was alright. My dad was pretty proud at one time. See, I had worked 28 years, maybe more than that. Maybe 28, 29 years. And I got to be a supervisor. And my dad thought that was pretty [Carl's wife, Carolyn: It was a salaried position.] Salary position. I retired as a salary position. And he thought that was pretty nice. [Carolyn: Yeah, he made his daddy proud.] Because in the old days, salaried people were always thought to be better than other ones, which they weren't. But, you know, they worked. So, he thought that was kind of nice that I got that job. (Emphasis added)

In this case, it was okay for his father to be proud of his accomplishments. But Carl maintained his humility by making a point of saying that salaried people, including himself were not any better than hourly workers.

These messages, lessons, and anecdotes lay the groundwork for the working class value of humility. This value also was demonstrated in talk regarding people remaining humble about their achievement, recognizing that other jobs are equally important, and demonstrating a willingness to do work that other people may perceive to be below their position. Humility was particularly important for socially mobile individuals who were taught that, should they rise out of a working class position, they should retain the same humility and not, in turn, look down on people in job roles perceived by society to be beneath them. 


\section{The Working Class Promise}

Taken together, the values communicated in workers' stories and personal histories are more than simply a way to bring value to the working class. Given the consistency and intensity with which these stories were told, they also forwarded a mandate to uphold these values and to maintain a working class identity. As such, I coin the larger discourse as the Working Class Promise. In the most basic terms, the Working Class Promise translates into a commitment to uphold the core set of shared values revered by working class communities (i.e., work ethic, provider orientation, dignity of all work and workers, humility) and, by extension, to maintain one's working class membership and identity.

Like the American Dream, the Working Class Promise is a widespread and important ideology that has implications for individuals' careers, particularly for people with working class ties. It is important to note that the Working Class Promise does not replace the American Dream; instead, it is layered with the American Dream. The Working Class Promise discourse not only provides a reason for work (to be a provider) and directs how work should be done (strong work ethic), but it also privileges ethics related to work-based attitudes (dignity and humility). Because the ideology crafts such a resoundingly positive identity, the working class becomes a position of pride and honor. Therefore, the career-related goal of this discourse is to maintain working class membership and identity - a goal that runs counter to the American Dream.

\section{Ambivalences and Negotiating the Paradox}

In this section, I begin by explaining how the discourses of the American Dream and the Working Class Promise socially construct a structural paradox (see Connidis \& McMullin, 2002), which is the source of social mobility-based ambivalences. Then, I demonstrate how individuals who achieve social mobility engage in identity work to negotiate, with greater and lesser success, the paradox of their mobility.

\section{The Paradox of the Promise and the Dream}

To understand the structural paradox of the Promise and the Dream, it is necessary first to understand how social class hierarchies are outlined by the two discourses. The American Dream discourse, which encourages the goal of social mobility, assumes a social class structure that is aligned closely with basic sociological models. Even though there is some diversity in these models (e.g., pyramids, boxes, double-diamonds; see Perrucci \& Wysong, 2003), the basic premise is that there is a small upper class on top, a large middle class in the center (within which a sizeable working class is situated, usually at the lower end), and a small lower class on the bottom (for a simplified version, see Figure 1). Therefore, in the American Dream discourse, particularly in the materialistic variant, the idea of climbing the ladder is indicative of a highly reified social structure based on socioeconomic bounded categories. 


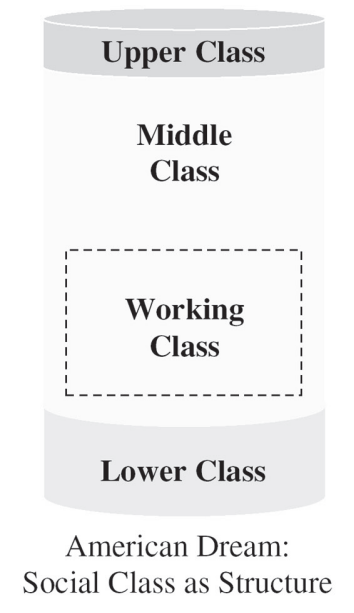

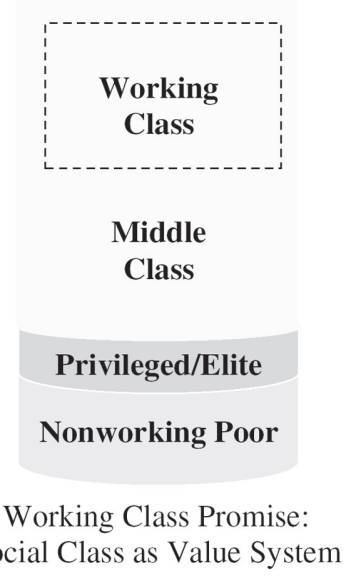

Figure 1. Repositioning of social classes.

In contrast, the Working Class Promise views class as a socially constructed value system. Because the working class is regarded so positively within the framework of the Working Class Promise, the large working class, which typically is positioned in the lower-center, rises to the top. Then both the upper class (which is redefined as the privileged/elite who do not have to work) and the lower class (which is redefined as the nonworking poor who "choose" not to work) move below.

The privileged/elite are positioned above the nonworking poor because many of these people, although wealthy, do have jobs. Yet, they are excluded from the working class based on assumptions that they may privilege a poweror wealth-building perspective over a provider orientation, may not respect the dignity of working class jobs and job incumbents, and/or may not be sufficiently humble about their success. Tracy raised direct criticism, "I think they [the upper class] look down at the working class even though it's like there's [sic], I perceive, a lot of immorality within these sort of non-working class type people." Kathleen criticized people who were "living on the hard work that your parents did and living off of their labors." Because some people who do not have to work still may hold jobs or make a contributions to the community through volunteer work, they are held in higher regard than the nonworking poor. In this sense, it is the act of working that earns them some respect and positions them above the nonworking poor.

The nonworking poor are considered to be at the bottom of the social class hierarchy as they are viewed as a burden on society and violating the most essential working class value of hard work (see Bernstein, 1997). Complaining about the number of people collecting state aid, Oscar bluntly said that people should work unless they are "really crippled or really retarded or really something wrong with you." Vincent was less harsh in his criticism of people who do not work, but basically agreed with Oscar: 
That's why you see people that won't go to McDonalds and flip hamburgers, 'cause that's not a real job, they figure. But it's close to six bucks an hour, so they should be going there. At least until they find something better.

In Vincent's opinion, people should work the best job they have available to them. If someone forgoes a job opportunity because they think it is not "real" (see Clair, 1996), then it is a violation not only of hard work, but also of humility. That is, being too proud to take a job that is a real job (as all jobs are real from the perspective of the Working Class Promise) demonstrates both the person's laziness and arrogance.

This repositioning of social classes is based largely upon viewing social class as a socially constructed value system, but some material facets were still considered. Specifically, rather than discrediting or resisting socioeconomic boundaries that typically delineate social classes, these blue-collar family members accepted those boundaries through both their talk and their silence. For instance, they described working class values as being inherently tied to working class and blue-collar jobs, modest incomes, and modest educational attainment. Additionally, there were no complaints of socioeconomic boundaries being flawed or problematic. As such, the Working Class Promise provides only a partial social (re)construction of social class.

When typical socioeconomic boundaries of social class structure (i.e., determining someone's social class position by markers such as occupation, education, and income) are accepted by adherents to the Working Class Promise, a structural paradox arises. The class-as-social-structure view posited by the American Dream and the class-as-value-system communicated by the Working Class Promise create paradoxical views of social mobility. As a case in point, consider a son or daughter of a blue-collar laborer who pursues a middle or upper class occupation (e.g., lawyer, banker). As indicated by the arrows in Figure 2 , this instance of intergenerational mobility is viewed in terms of the American Dream as an upward movement from a working class point of origin to a middle or upper class position. However, this very same sociological status change (from working class to middle or upper class) is viewed from the perspective of the Working Class Promise as a downward movement. Put simply, in the case of working class social mobility, to succeed at the American Dream necessarily means to fail at keeping the Working Class Promise. Thus, it is natural for ambivalences to arise as someone cannot be fully successful at one, without failing at the other.

\section{Negotiating the Paradox}

In the sense that the structural ambivalence of social mobility is constructed through communication, it also is negotiated through communication, specifically through identity work. Lüscher (2002) explains that ambivalence is both a burden (in the sense of psychological discomfort), but also a chance. He says that people "must live with ambivalence" but they "can cope with it in more or less competent, productive ways" (p. 587). Whereas Connidis and McMullin (2002) argue that relationally based ambivalences are negotiated in interaction, I argue 


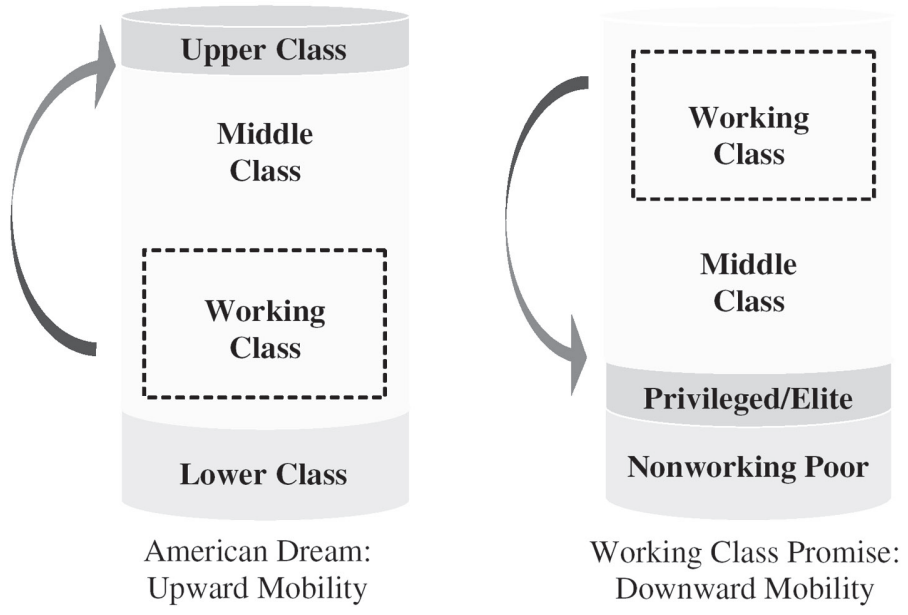

Figure 2. Incompatible goals of American Dream and Working Class Promise. A move from the working class to the middle or upper classes is viewed as upward mobility by the American Dream discourse and downward mobility by the Working Class Promise discourse.

that intrapersonally based ambivalences are negotiated through identity work. Identity work is a complex and inherently communicative process in that it is a negotiation of simultaneously held identities and individualized meaning making in interaction with people and systems (Alvesson, Ashcraft, \& Thomas, 2008; Hogg, 2006; Scott, 2007). Below I provide exemplars of how people who are ambivalent about their social mobility engage in identity work to negotiate (with greater and lesser success) their complex relationship to social class.

For straddlers, those people from blue-collar roots who achieve upward social mobility (Lubrano, 2004), the negotiation is a complex one. They feel strong pressure to be both achievers of the Dream and keepers of the Promise. But given the structural paradox of these two discourses, it is not surprising that strong ambivalences arise.

Chad, who has a lucrative job in a high-tech industry, acknowledges vividly the ambivalences associated with social class mobility. When he first landed his most recent job, which came with a sizeable raise, he said he was tormented with feelings of being "a fraud" and would stay awake at night filled with anxiety figuring out how he could "prove to people [he] was worth that position." With time, he recognized he was qualified to do his job well and that he indeed was not a fraud. Yet, he remained highly ambivalent about his professional successes, both appreciating and regretting his social mobility. For example, he said, "Yeah, I guess I aspire someday to not be working class. But there's a nobility in being working class, to go out there and earn that paycheck stub." Chad was particularly concerned about how his mobility affected his personal relationships with his childhood friends:

The friends that you've had all your life, suddenly it's not quite the same because now you have money and they don't. I like the friends that I've got. And 
I'd hate to see anything affect that. Those guys are lot more working class than I am, I guess. You know, I have to try to humble myself a little bit. Like not be showy about money or being able to buy things. I mean I can buy stuff after a couple paychecks that these guys, you know, couldn't all their lives. Well I shouldn't say all their lives. But it'd take them years to save up to buy something like that. And in a way, it's uncomfortable having money, having more money, because I don't want to make them uncomfortable around me. I'd rather be in that same position. "Yeah, I'm scrimping and saving too." Even though they look at my house and they'll say, "Nah, he's not scrimping and saving as much as I am." It's a hard, it's a hard balance.

Chad recognizes that it was his hard work that earned him his current position, but instead of unabashed pride in his accomplishments, he has an uneasy humility about his success:

But yet I'm self-conscious because I got that money and I don't want to be the cheese-eating, white-collar guy that everything has come easy to. Because well not everything came easy. But on the other hand, you know it's a whole hell of a lot easier for me now financially than it is for them. So you know it's a nerve wracking thing.

Chad expresses much ambivalence about his social mobility and his class-based identity. He respects the working class values with which he was raised, and sees his socioeconomic move from a working class origin to an affluent career and community as somehow betraying those values. Even though he advanced in his career as he did because of hard work (putting in 12-14 hour days) and is careful to be humble about his position with his childhood friends, he engages in private and public identity work as he tries to present himself as being on a par (class-wise) with his friends. For example, he told a story of wanting to buy a special gift for a friend, but hesitated to do so because he was afraid that the high price tag would make his friend uncomfortable.

Sarah, who is a middle manager at an international corporation, expressed her ambivalence in her definition of working class. She was one of the few in the younger generation to mention any negative aspects of the working class. But she qualified her critique by also calling upon a family orientation that overrides any dissatisfactions of a job:

Working class is to me, is people that live paycheck to paycheck. Don't really have a savings. I wouldn't consider a working class person to be very happy with where they are in their lives. They would have wanted more for themselves. The term working class, I guess, I would label that way. But I would picture them to be very family-oriented, too, though. Because they would see the value of their time with their family and not so much how much money they are earning.

What is surprising about Sarah is that following her sharp definition of working class, she said she "definitely" considered her parents to be working class, as well as herself. She said:

I don't think I'm a big exec that's, you know, got the world by the tail. But I think that I'm better, I know that I'm better off income-wise than the average person. So I guess, income-wise I would label myself as being a little bit higher than the 
average. But my importance of my family, I think, is healthy. And in fact most recent decisions I've made personally, I've made thinking more as a mom than as a professional. So working class mentality family-wise, I think I've got that.

In Sarah's case, she begins by offering a mix of criticism and praise for the working class, citing American Dream type critiques of lesser professional success, but extolling some of the core value system. In her own class-based identification, she sticks to the objective fact of her income making her "better off " than the average person (which is an indication of achieving the materialistic American Dream), but aligning herself with family values that attest she still is loyal to her working class roots and value system.

Brenda, perhaps, was the clearest example of someone who was able to weave together her social mobility and her Working Class Promise values. Brenda is a senior-level executive at a financial company. She has created a life that is filled with many luxuries. She talks vividly about the road bumps to mobility she experienced and how she and her husband are dedicated to preparing their son for an easier navigation of professional life. Yet, she expresses psychological ambivalence about class-based distinctions. When asked what the term working class meant to her, she responded passionately:

Blue-collar, white-collar. I hate those parameters. I really, truly do. They, again, were more utilized in my vocabulary in my younger days. And you have this sense of, I think that separates people into classes. It's very biased and very negative. I don't like those definitions. And it just bothers me. Because it just separates our society instead of uniting it. And it seems to devalue people who don't go and get formal education. It shuts people off, somewhat like, you know, being racist. It shuts people off from ever learning about people.

In part defending her blue-collar parents and siblings, Brenda continued:

So I don't like pigeon-holing. And I think we create a definition based on what we hear is that working class is the type of people that never went beyond high school or didn't finish high school. And they settled. I think that's the negativism we have. Where I try to view the working class as every one of us, every day, who has to take on life and be challenged. No matter what. Whether they go to a building or stay at home or whatever they do. Life is work. So I don't like boxes. I really don't.

In contrast to Chad, who viewed his social mobility as somewhat of a betrayal of his Working Class Promise, Brenda was able to craft her identity in a way that credited the Working Class Promise as a catalyst for her achievement of the American Dream.

I value that I'm where I am at. Because I can appreciate what life has to offer and I can experience more that life has to offer. And I'm not as limited. And yes, the value of being raised in that traditional blue-collar is family is very valued and important. And the strong work ethic, just the overall having to work hard. And there's something to be said for appreciating things a lot more when you have to work for them versus something that has been given to you.... Whether you call them white-collar, blue-collar, I don't even care, I just want to reach my goal. And I want to do that with maintaining the values I was raised with. And that's it. 
Some participants acknowledged similar negotiations of the American Dream and Working Class Promise on behalf of close friends and family members who were socially mobile. For instance, Matthew, who describes himself as struggling to be in the "lower middle class" of working class, echoes Brenda's sentiments in a description of his brother who rose from humble working class beginnings to an upper class career.

\begin{abstract}
Most of those people up in the better positions probably came from the lowermiddle working class where their value of what they do is kind of instilled in them. You know, life is better, but they haven't forgotten. They haven't forgotten their upbringing, their values. They've changed, but not totally. I think there's a lot. My brother's a good example of that. Both him and his wife make six-figures. Came from lower-middle class. But their values haven't changed all that much. They're not that much different than me.
\end{abstract}

These identity negotiations demonstrate the work involved in discursively constructing a position where socially mobile individuals could be both achievers of the American Dream and keepers of the Working Class Promise. Those who were better able to separate working class values from socioeconomic boundaries (like Brenda and Sarah) were able to manage their ambivalences more productively. But for those who saw the material and discursive components of working class structures inextricably linked (like Chad), social mobility ambivalences ran much deeper.

\title{
Discussion
}

In summary, the Working Class Promise is an important cultural discourse that socially constructs the working class as a constellation of highly regarded values: work ethic, provider orientation, dignity of all work and workers, and humility. This discourse plays an important role in creating a resoundingly positive group identity in place of stigmatized identities often associated with blue-collar and working class people (e.g., Alper, 2005; Butsch, 2003). However, it also carries important implications for people from working class roots who achieve social class mobility.

This essay provides a theoretical account for why social mobility-based ambivalences exist. Specifically, the differing ways that social class is understood by the American Dream and Working Class Promise discourses (by socioeconomic status and by a value-based system, respectively) mean that class structure is repositioned in ways that create contradictory expectations for mobility. Whereas the goal of the American Dream is to rise out of the ranks of a lower social class (e.g., the rags-to-riches storyline), the goal of the Working Class Promise is to maintain membership in the class by upholding a shared, work-related value system.

In more theoretical terms, the discourses of the American Dream and Working Class Promise communicatively construct a structural paradox that gives rise to sociological ambivalences of social mobility (Connidis \& McMullin, 2002). These two discourses separately and simultaneously assign meaning to social classes. But social construction not only gives meaning to objects, it 
also directs how individuals and society react in response to those objects (Allen, 2005). In the case of working class people, it means that those individuals who are exposed to both the American Dream and the Working Class Promise are presented with two sets of diverse beliefs and paradoxical goals: on one hand, working class is a starting point, a social position one should strive to rise above; on the other, working class is an esteemed endpoint, a social position one should strive to maintain.

Merton and Barber (1963) maintain that the primary source of sociological ambivalences related to social class mobility is the clash between different sets of cultural rules. Research indeed has documented many of the challenges of crafting new social class identities, such as altering speech patterns, changing ways of dressing, and shifting friendship bonds (e.g., Kaufman, 2003; Lubrano, 2004). Navigating different sets of cultural rules can create tensions and ambivalences, but the current research demonstrates that it, instead, may be the contradictory cultural values briefly mentioned by Merton and Barber that are at the core of the most deeply seated sociological ambivalences. Namely, people who are socially mobile must negotiate contradictory cultural mandates of both maintaining and rising above their social class of origin. Consequently, feelings of ambivalence should be expected as straddlers must engage in complex negotiations of identity work to align their class-based identities in such ways to position themselves as both achievers of the American Dream and keepers of the Working Class Promise.

Admittedly, there is much overlap between the American Dream and Working Class Promise, particularly in regard to the centrality of work ethic in both discourses. Especially when taken in a more holistic sense (i.e., balancing the materialistic and moralistic myths), the Working Class Promise and American Dream are largely compatible discourses. This compatibility is particularly apparent for the lower rungs of the working class, as people draw upon values of the Working Class Promise to help them achieve the American Dream through incremental advancement (Newman \& Chen, 2007). It is also the case for people in the poor and lower classes, whether they achieve lower- to middle-wage working class jobs (Newman, 1999, 2006) or great wealth (Cloud, 1996; Gardner \& Troupe, 2006). In these scenarios-from lower-working class to upperworking class and from nonworking poor to privileged/elite-social mobility is deemed upward advancement by both discourses. Therefore, for many people the American Dream and Working Class Promise are complementary rather than contradictory, which further obscures the tensions for the socially mobile.

Recognizing the paradox of the American Dream and Working Class Promise is not an easy task. To begin, when each discourse is viewed separately, neither one is particularly remarkable. Consequently, they are easy to dismiss from critical attention. Second, these discourses are structured in ways that make the contradictions difficult to detect. Whereas the American Dream foregrounds the goal of social mobility and backgrounds its understanding of class construction, the Working Class Promise does the opposite. It foregrounds its understanding of class and backgrounds the goal. These nuanced approaches serve to obscure the inherent tensions between the two. Therefore, it is difficult to recognize the subtle ways in which these competing cultural demands 
operate. Third, resistance to identifying with a social class in our postindustrial economy is another barrier to negotiating the contradictions (Savage et al., 2001; Sayer, 2002). If change is to occur, people will have to be much more willing to engage in conscious thought and discussion about social class.

Further inquiry into this area of research is important for advancing understandings of social mobility-based ambivalences. In particular, future research should test the transferability of the Working Class Promise by looking at other working class populations. Important insights could be gained from diversity across different occupations, geographic areas, races, generational cohorts, and other important markers of difference. If the Working Class Promise discourse, or variations of it, is present across different populations, it will strengthen the concept and underscore its cultural significance.

Another important area of inquiry surrounds the presence of the Working Class Promise in public discourse, particularly as it relates to political speech and social class debate. For example, in the 2008 presidential election, "Joe the Plumber," a 30- something working-class man from Ohio, garnered the national spotlight when candidates Obama and McCain repeatedly centered their economic debates on which political party's proposed policies would best enable "Joe" to achieve the American Dream (see Wurzelbacher \& Tabback, 2009). Another recent example comes from recent debate on a talk show that focused on the politics of working poor families. Callers raised passionate challenges to the meanings of working class and the American Dream (C-SPAN, 2011). Research in this area would help to understand how the Working Class Promise discourse functions in the public sphere.

In conclusion, ambivalences of social class mobility persist. Moreover, these ambivalences go beyond learning to navigate a new set of cultural rules (Kaufman, 2003; Lubrano, 2004). They also include the more challenging task of negotiating contradictory cultural values and expectations (Merton \& Barber, 1963) that profoundly affect individuals' own class-based identifications. This essay took a step toward providing a theoretically grounded explanation of why these ambivalences are perpetuated and how people are engaging in complex identity work to manage the contradictions. The American Dream and the Working Class Promise - which can be fully understood only when examined together - point to the complexity of class-based identity negotiations and the ongoing salience of social class in contemporary life.

\section{Note}

[1] The participants for this study represented 20 families from a small, blue-collar community in the Midwestern United States. They included a group of men $(n=21)$ who worked in blue-collar positions in the mining industry, their wives $(n=16)$ who held a variety of occupations from nursing to retail to factory work, and their adult sons $(n=12)$ and daughters $(n=13)$, who worked in a variety of industries, including financial, medical, engineering, education, military, and skilled trades. The older generation's ages ranged from their early-50s through their late-70s and the younger generation ranged from their early-30s through their early-40s.

I conducted in-depth, semistructured interviews with each participant. As this was part of a larger study, questions focused on occupational history and occupational deci- 
sion making, communication-based anticipatory socialization, and their on-the-job experiences. At the end of each interview (as to not sensitize participants to social class), I posed the question, "What does the term working class mean to you?" The interviews cumulated in more than 60 hours of recorded talk. I transcribed and verified their interviews. I replaced participants' names with pseudonyms and cross-checked family members' transcripts to ensure all real names were masked. Transcription resulted in more than 1000 pages of single-spaced text. Data analysis was guided by grounded theory and methods (Glaser \& Strauss, 1967; Strauss \& Corbin, 1994). Glaser and Strauss (1967) explain that grounded theory is an inductive approach to theory building that privileges data and allows themes and theory to emerge naturally, rather than testing data against a priori theoretical frameworks. It involves multiple, iterative, close readings of data, beginning at the point of data collection. I sensitized myself to issues of social class as I analyzed participants' words. What does the term working class mean to them? How are they talking about class even when they are not being specifically queried about it? Throughout the iterative process of data analysis and open coding, I wrote memos that summarized relationships between emerging codes, captured my impressions and insights into the data, and elaborated on key conceptual issues (Glaser, 1978). I often returned to holistic accounts, reviewing case summaries and field notes, rereading entire transcripts, and listening to original recordings to gain a richer, more complete understanding of participants' discourses.

\section{References}

Adams, J. T. (1931). The epic of America. Garden City, NY: Blue Ribbon Books.

Allen, B. J. (2005). Social constructionism. In S. May \& D. K. Mumby (eds.), Engaging organizational communication theory and research: Multiple perspectives (pp. 35-53). Thousand Oaks, CA: Sage.

Alper, L. (2005). Class dismissed: How TV frames the working class. [Video]. Northhampton, MA: Media Education Foundation.

Alvesson, M., Ashcraft, K. L., \& Thomas, R. (2008). Identity matters: Reflections on the construction of identity scholarship in organization studies. Organization, 15, 5-28; doi:10.1177/1350508407084426

Ashforth, B., \& Kreiner, G. E. (1999). “How can you do it?": Dirty work and the challenge of constructing a positive identity. Academy of Management Review, 24, 413-434.

Berger, P. L., \& Luckmann, T. (1966). The social construction of reality: A treatise in the sociology of knowledge. Garden City, NY: Doubleday.

Bernstein, P. (1997). American work values: Their origin and development. Albany: SUNY Press.

Butsch, R. (2003). A half century of class and gender in American TV domestic sitcoms. Cercles, 8, 16-34.

Buzzanell, P. M. (2000). The promise and practice of the new career and social contract. In P. M. Buzzanell (ed.), Rethinking organizational and managerial communication from feminist perspectives (pp. 209-235). Thousand Oaks, CA: Sage.

Carroll, R. (2002). No free lunch: One man's journey from welfare to the American Dream. New York, NY: One World/Ballantine.

Christopher, R. (2002). Rags to riches to suicide: Unhappy narratives of upward mobility. College Literature, 29(4), 79-108.

Clair, R. P. (1996). The political nature of the colloquialism, "a real job": Implications for organizational socialization. Communication Monographs, 63, 249-267; doi:10.1080/03637759609376392 
Cloud, D. L. (1996). Hegemony or concordance? The rhetoric of tokenism in "Oprah" Winfrey's rags-to-riches biography. Critical Studies in Mass Communication, 13, 115-137; doi:10.1080/15295039609366967

Connidis, I. A., \& McMullin, J. A. (2002). Sociological ambivalence and family ties: A critical perspective. Journal of Marriage and Family, 64, 558-567; doi:10.1111/j.1741-3737.2002.00558.x

Coser, R. L. (1966). Role distance, sociological ambivalence, and transitional status systems. American Journal of Sociology, 72, 173-187.

C-SPAN. (2011, January 3). Low-income families. Washington Journal [Television call-in show]. Washington, DC.

DeSantis, A. D. (1998). Selling the American Dream myth to black southerners: The Chicago Defender and the Great Migration of 1915-1919. Western Journal of Communication, 62, 474-511; doi:10.1080/10570319809374621

DeVitis, J. L., \& Rich, J. M. (1996). The success ethic, education, and the American Dream. Albany, NY: SUNY Press.

Engen, D. (2004). Invisible identities: Notes on class and race. In A. González, M. Houston, \& V. Chen (eds.), Our voices: Essays in culture, ethnicity and communication (4th ed, pp. 250-255). Los Angeles, CA: Roxbury.

Fisher, W. R. (1973). Reaffirmation and subversion of the American Dream. Quarterly Journal of Speech, 56, 160-167; doi:10.1080/00335637309383164

Gardner, C., \& Troupe, Q. (2006). Pursuit of happyness. New York, NY: Harper Paperbacks.

Glaser, B. G. (1978). Theoretical sensitivity: Advances in the methodology of grounded theory. Mill Valley, CA: Sociology Press.

Glaser, B. G., \& Strauss, A. (1967). The discovery of grounded theory: Strategies for qualitative research. Chicago, IL: Aldine Publishing.

Hall, D. T., \& Goodale, J. (1986). Human resource management. Glenview, IL: Scott, Foresman \& Co.

Hogg, M. A. (2006). Social identity theory. In P. J. Burke (ed.), Contemporary social psychological theories (pp. 111-136). Stanford, CA: Stanford University Press.

Kamp, D. (2009, April). Rethinking the American Dream. Vanity Fair. Retrieved from http://www.vanityfair.com/culture/features/2009/04/american-dream200904

Kaufman, P. (2003). Learning to not labor: How working-class individuals construct middle-class identities. Sociological Quarterly, 44, 481-504.

Lamont, M. (2000). The dignity of working men: Morality and the boundaries of race, class, and immigration. Cambridge, MA: Harvard University Press.

Lubrano, A. (2004). Limbo: Blue-collar roots, white-collar dreams. Hoboken, NJ: Wiley.

Lucas, K. (2007). Problematized providing and protecting: The occupational narrative of the working class. In W. DeGenaro (ed.), Who says? Working-class rhetoric, class consciousness, and community (pp. 180-199). Pittsburgh, PA: University of Pittsburgh Press.

Lucas, K. (2011). Blue-collar discourses of workplace dignity: Using outgroup comparisons to construct positive identities. Management Communication Quarterly, 25, 353-374; doi:10.1177/0893318910386445

Lüscher, K. (2002). Intergenerational ambivalence: Further steps in theory and research. Journal of Marriage and Family, 64, 585-593; doi:10.1111/j.1741-3737.2002.00585.x

Lüscher, K., \& Pillemer, K. (1998). Intergenerational ambivalence: A new approach to the study of parent-child relations in later life. Journal of Marriage and Family, 60, 413-425.

Merton, R. K., \& Barber, E. (1963). Sociological ambivalence. In E. A. Tiryakian (ed.), Sociological theory, values, and sociological change: Essays in honor of Pitirim A. Sorokin (pp. 91120). New York, NY: Free Press. 
Newman, K. S. (1999). No shame in my game: The working poor in the inner city. New York, NY: Russell Sage Foundation.

Newman, K. S. (2006). Chutes and ladders: Navigating the low-wage labor market. New York, NY: Russell Sage Foundation.

Newman, K. S., \& Chen, V. T. (2007). The missing class: Portraits of the near poor in America. Boston, MA: Beacon Press.

Nomai, A. J., \& Dionisopoulos, G. N. (2002). Framing the Cubas narrative: The American Dream and the capitalist reality. Communication Studies, 53, 97-111.

Pearce, W. B. (1994). Interpersonal communication: Creating social worlds. New York, NY: HarperCollins.

Pearce, W. B. (1995). A sailing guide for social constructionists. In W. Leeds-Hurwitz (ed.), Social approaches to communication (pp. 88-113). New York, NY: Guilford Press.

Perrucci, R. L., \& Wysong, E. (2003). The new class society: Goodbye American Dream? (2nd ed). Lanham, MD: Rowman \& Littlefield.

Register, C. (2001). Packinghouse daughter: A memoir. New York, NY: Perennial.

Rowland, R. C., \& Jones, J. M. (2007). Recasting the American Dream and American politics: Barack Obama's keynote address to the 2004 Democratic National Convention. Quarterly Journal of Speech, 93, 425-448; doi:10.1080/00335630701593675

Savage, M., Bagnall, G., \& Longhurst, B. (2001). Ordinary, ambivalent and defensive: Class identities in the northwest of England. Sociology, 35, 875-892; doi:10.1177/ 0038038501035004005

Sayer, A. (2002). What are you worth? Why class is an embarrassing subject. Sociological Research Online, 7(3).

Scott, C. R. (2007). Communication and social identity theory: Existing and potential connections in organizational identification research. Communication Studies, 58, 123-138; doi:10.1080/10510970701341063

Sennett, R., \& Cobb, J. (1972). The hidden injuries of class. New York, NY: W. W. Norton.

Serafin, T. (2007, June 26). Rags to riches billionaires. Forbes. Retrieved from http://www. forbes.com/2007/06/22/billionaires-gates-winfrey-biz-cz-ts-0626rags2riches.html

Shotter, J., \& Gergen, K. J. (1994). Social construction: Knowledge, self, others, and continuing the conversation. In S. Deetz (ed.), Communication yearbook 17 (pp. 3-33). Thousand Oaks, CA: Sage.

Strauss, A., \& Corbin, J. (1994). Grounded theory methodology: An overview. In N. K. Denzin \& Y. S. Lincoln (eds.), Handbook of qualitative research (pp. 273-285). Thousand Oaks, CA: Sage.

Thomas, R. J. (1989). Blue-collar careers: Meaning and choice in a world of constraints. In M. B. Arthur, D. T. Hall, \& B. S. Lawrence (eds.), Handbook of career theory (pp. 354-379). Cambridge, UK: Cambridge University Press.

Wilson, J. L. (2002). Blue ring around a white collar: An application of marginality. ETC: A Review of General Semantics, 59(1), 25-31.

Winn, J. E. (2000). Moralizing upward mobility: Investigating the myth of class mobility in Working Girl. Southern Communication Journal, 66, 40-51; doi:10.1080/10417940009373185

Winn, J. E. (2003). Every dream has its price: Personal failure and the American Dream in Wall Street and The Firm. Southern Communication Journal, 68, 307-318; doi:10.1080/10417940309373269

Wong, Y. (2010). Social mobility and social inequality: The ambivalence of the middle class. Sociological Research Online, 15(2).

Wurzelbacher, S. J., \& Tabback, T. N. (2009). Joe the plumber: Fighting for the American Dream. Austin, TX: Pearlgate. 